\title{
Performance Evaluation of Artificial Floating Island for Nutrient Removal
}

\author{
Rohini N. Nitturkar ${ }^{1}$ \\ Student, \\ Environmental Science \& Technology \\ Department of Technology, Shivaji University, Kolhapur. \\ Kolhapur, Maharashtra, India.
}

\author{
Shrikant M. Bhosale ${ }^{2}$ \\ Assistant Professor, \\ Environmental Science \& Technology \\ Department of Technology, Shivaji University, Kolhapur. \\ Kolhapur, Maharashtra, India.
}

\begin{abstract}
Lake and pond are important source of water. Both have different environmental values. They play vital role in maintaining microclimate of surrounding area. Also, they have major environmental, social, cultural and aesthetical potency. The source of influent taken for the system was from Sangeet Talav which is situated at Shivaji University's campus area. This pond is important from environmental point of view as it supports aquatic as well as terrestrial ecosystem. The aim of this study was to investigate the feasibility and efficiency of Artificial Floating Island (AFI) for nutrient removal mainly total nitrogen and total phosphorus. AFI system with different vegetation is checked for the pond water. The AFI system with canna indica shows better performance for total nitrogen and total phosphorus removal than the system with other vegetation.
\end{abstract}

Keywords: Artificial Floating Island, Total Nitrogen, Total Phosphorus, Pond Water

\section{INTRODUCTION}

Degradation of the surface water bodies like rivers and lakes/ponds are one of the most important environmental issues in recent years. Perhaps the most serious threat to stagnant water body is nutrient enrich surface runoff and discharge of septic wastewater. The presence of excessive nutrient in a water body encourages the growth of algae, duckweed, water hyacinth, phytoplankton and other aquatic plants.

The eutrophication of inland water is mainly caused by the human activities including rapid urbanization, industrialization and intensive agricultural production especially excessive use of fertilizers in field. Therefore, nitrogen and phosphorus enriched waste from point and non-point sources enters into natural water bodies and have become a severe water pollution problem in many countries. Hence, this has led researchers to search for creative, cost-effective and environmentally sound ways to control water pollution. One of the technologies is Artificial Floating Island. The Artificial Floating Island (AFI) is a technique of wetlands in which substratesrooted plants and free-floating wetland plants are used.

\section{II.ARTIFICIAL FLOATING ISLAND TECHNIQUE}

The AFI consist of aquatic or native plants growing in hydroponic manner with buoyant structures floating on the surface of water.

Beside reduction of nutrient level in natural water bodies AFI has other functions such as water purification by entrapping suspended solids in their extensive root system below the water level, creation of habitat for fish and birds and to improve the landscape. The technique of this method is to stock nutrient inside the living creature i.e. nutrient is not taken outside the system. The plant products produced by AFI can be easily harvested without disturbing much system and subsequently used as cattle feed and can be processed into compost. So, it impels the practical application of the technology due to the possible economic returns. The objectives of the experiments were:

a. To determine the rate of total nitrogen and total phosphorus removal from the pond water by this technique.

b. Its effect on $\mathrm{pH}$ and dissolved oxygen of the pond water.

c. To compare the performance of AFI system planted with three different species.

\section{SOURCE OF POND WATER}

The Shivaji University, Kolhapur has campus area of 380 hectare. It has many education department buildings, student hostels, playgrounds, plantation for afforestation and many other section buildings. So, considering large surrounding of the university and activities taking place within its premises, the water supply was not enough. Therefore, to increase availability of water within the university premises, pond was constructed in the year of 2007-08. This pond is known as Sangeet Talav. This pond is situated at latitude $16^{\circ} 40^{\prime} 59.44^{\prime \prime}$ and longitude $74^{\circ} 15^{\prime} 13.98^{\prime \prime}$ in the depression of north side university campus. The pond has catchment area of about $0.244 \mathrm{sq} . \mathrm{km}$. It has maximum flood flow up to $6.51 \mathrm{~m} 3 / \mathrm{sec}$, total storage capacity of about 99.50 million cubic feet and total stored water 1.86 million cubic feet. The length of embracement of dam is $175 \mathrm{~m}$ and height is $6.55 \mathrm{~m}$. The sample required as influent to the system were taken from a sampling point decided considering various conditions present. 


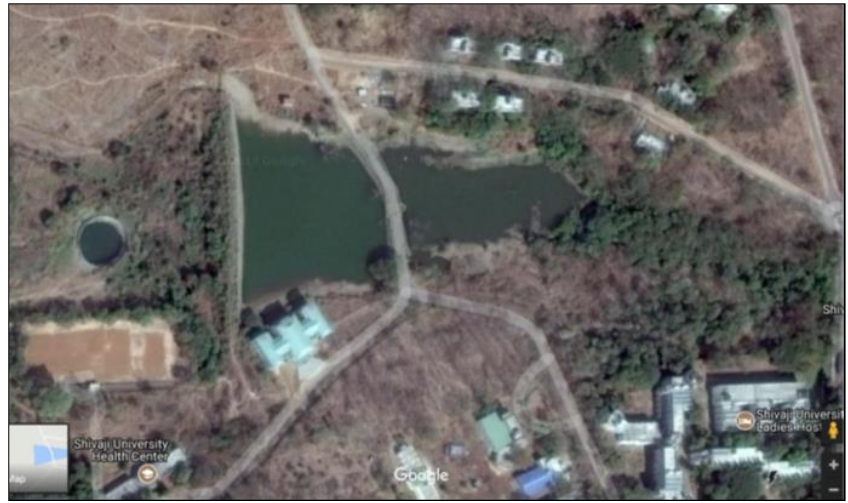

Fig.1 Google earth image of Sangeet Talav

\section{MATERIAL USED FOR PREPARATION OF MODEL}

\section{a. Water retaining tank}

The reactor was formed using the plastic tub having outer dimensions of $51 \mathrm{~cm} \times 21 \mathrm{~cm} \times 16 \mathrm{~cm}$ and inner dimensions of $50 \mathrm{~cm} \times 20 \mathrm{~cm} \times 16 \mathrm{~cm}$ which has a capacity of 16 liters. A tap of 0.5 inches was connected at the bottom of the reactor to withdraw the effluent.

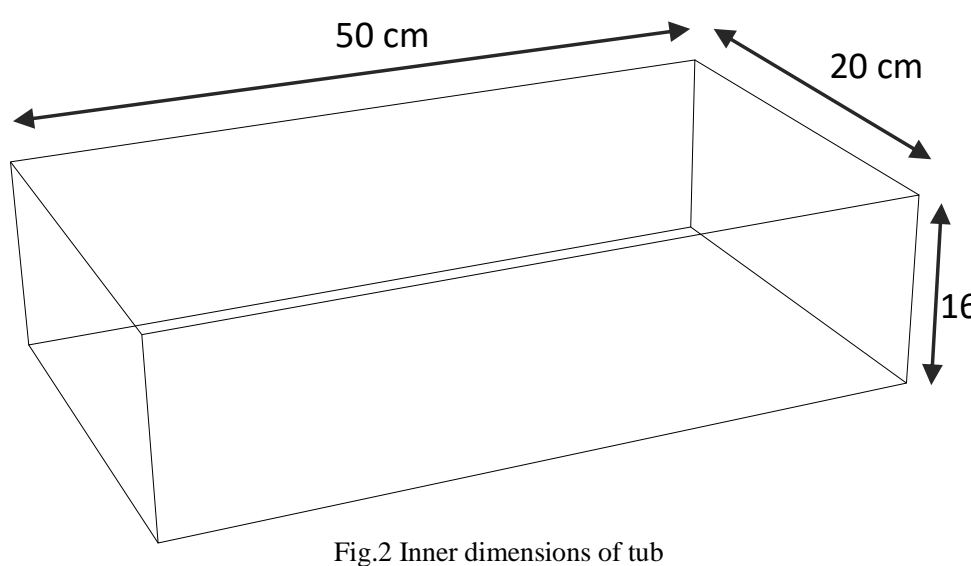

Fig.2 Inner dimensions of tub

\section{b. Floating Platform}

Floating media helps to buoyant the plants. A rectangular frame of PVC pipe of diameter $1.3 \mathrm{~cm}$ was made on which plastic mesh is tied. Plastic thermocol was provided below the plastic mesh. This plastic thermocol ensures maximum floating and supports plastic mesh. This plastic thermocol is provided in such way that it makes six compartments. In each compartment approximately $2 \mathrm{~cm}$ hole was made so as to insert vegetation root below the mesh.

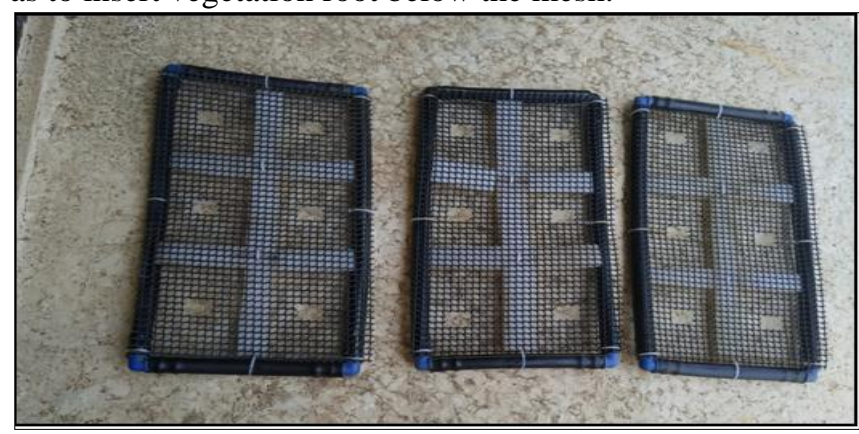

Fig.3 Photographic views of floating platform

\section{c. Coconut Palm Fibers}

Mostly coconut palm fibers are used as a base for vegetation. This also acts as a medium for anchorage. As a result of heavy silica content, with hardly any decomposition the coir can also sustain for 6 years of water logging. It is used as a substratum (as a substitute for soil) for growing vegetation. It is a product that is environmentally safe and long-lasting. It's also lighter and more buoyant. Coir's chemical structure is 45.84 percent lignin, 43.44 percent cellulose, 0.25 percent hemi cellulose, 3 percent protein and associated compounds, 5.25 percent water soluble, and the physical characteristics are 24-32 $\mathrm{mm}$ long, 30 percent breaking elongation, $0.1-1.5 \mathrm{~mm}$ diameter (17).

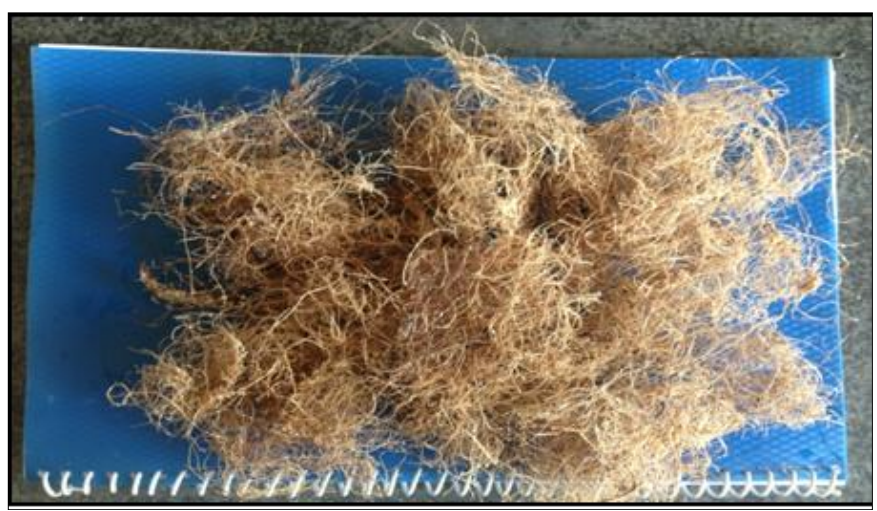

Fig. 4 Photographic views of coconut palm fibers

\section{d. Vegetation}

$16 \mathrm{~cm}$ The performance of AFI for total nitrogen and total phosphorous was evaluated for three different vegetation which are cyprus scariosus, typha minima and canna indica. These plants are adaptable to local climate, perennial plants, having ability to thrive in a hydroponic environment, tolerance to adverse concentration of pollutants and adverse climatic conditions and ease of management.

\section{PROCESS DESCRIPTION}

Lab scale models were built to check nutrient removal efficiency of AFI. Grab sampling was carried out to collect the pond water. Each time the cans were washed thoroughly with tap water and 3 times rinsed by pond water during sapling. At the initial stage of the experiment, 40 liters of wastewater was collected from the pond. The process was based on fill-and-draw principle. It consists of three steps fill, retain and discharge as follow:

Fill - During this step the system is filled with the pond water.

Retain - Pond water retain for different detention time.

Discharge - Effluent is drawn out of the reactor after complication detention time.

The most important design factors are the vegetation, percentage of vegetation coverage, the depth and the methods used to achieve buoyancy. For all three reactors method that is used for achieving buoyancy is same i.e. a rectangular frame of PVC pipe on which plastic mesh is tied and plastic thermacol is provided below the mesh. The 
surface coverage of floating platform is $0.0612 \mathrm{~m}^{2}$. The depth of water is also same for all reactors, around $0.3 \mathrm{~cm}$. The percentage of vegetation coverage was $52.7 \%$. This much vegetation coverage was covered by 6 plants per each floating platform. For emerging wetland vegetation, Tanner and Headly confirmed that max. root depths tend to range from $57-87 \mathrm{~cm}$. Therefore, to avoid macrophyte roots from attaching to the benthic substratum, the water depth of 1 to $1.2 \mathrm{~m}$ should be maintained.

Table 1 Details of experimental setup

\begin{tabular}{|l|c|c|c|}
\hline Parameters & $\begin{array}{c}\text { Reactor 1 } \\
(\mathrm{R} 1)\end{array}$ & $\begin{array}{c}\text { Reactor 2 } \\
(\mathrm{R} 2)\end{array}$ & $\begin{array}{c}\text { Reactor 3 } \\
(\mathrm{R} 3)\end{array}$ \\
\hline Surface area of reactor $\left(\mathrm{m}^{2}\right)$ & 0.10 & 0.10 & 0.10 \\
\hline Height of reactor (m) & 0.16 & 0.16 & 0.16 \\
\hline Depth of water (m) & 0.13 & 0.13 & 0.13 \\
\hline $\begin{array}{l}\text { Surface Area of floating } \\
\text { platform }\left(m^{2}\right)\end{array}$ & 0.0527 & 0.0527 & 0.0527 \\
\hline $\begin{array}{l}\text { Type of vegetation } \\
\text { Cyprus } \\
\text { scariosus }\end{array}$ & $\begin{array}{c}\text { Typha } \\
\text { minima }\end{array}$ & $\begin{array}{c}\text { Canna } \\
\text { indica }\end{array}$ \\
\hline
\end{tabular}

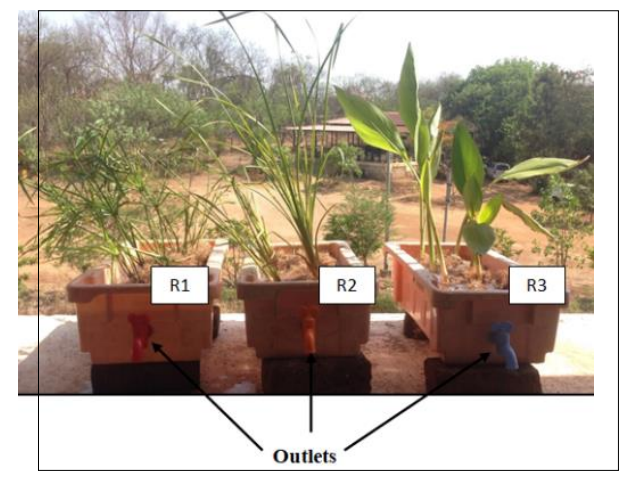

Fig. 5 Photographic views of all three reactors

The operations of system is given below:

a) Initially characterization of Sangeet Talav water was carried out for every month from August 2018to March 2019.

b) Young plants of cyprus scariosus, typha minima and canna indica were brought from nearby areas. The adaptation of plant species to pond water was ensured before starting the research.

c) These three reactors were characterized for the different detention time such as 2, 3, 4, 5 and 6 days. Optimum water depth was assumed. Each of the tanks was filled with 13 lit. pond water.

d) All reactors were filled with pond water.

e) Floating platform with vegetation was placed in the reactors.

f) Then observations were recorded and compared.

\section{RESULT AND DISCUSSION}

Apart from investigation of total nitrogen and total phosphorus removal efficiency, its alteration to $\mathrm{pH}$ and $\mathrm{DO}$ concentration of pond water was analyzed for inlet and outlet. All these parameters were monitored for 2,3,4,5 and 6 days detention time. Study was conducted on $8^{\text {th }}$ May.
The wastewater depth of 1 to 1.2 is recommended. The number of plant is recommended as 114 per $\mathrm{m}^{2}$.

Table 2 Observed $\mathrm{pH}$

\begin{tabular}{|c|c|c|c|c|}
\hline $\begin{array}{c}\text { Detention } \\
\text { Time }\end{array}$ & Inlet & R1 outlet & R2 outlet & R3 outlet \\
\hline 2days & 6.49 & 6.28 & 6.11 & 6.09 \\
\hline 3days & 6.3 & 5.9 & 6.1 & 5.7 \\
\hline 4days & 6.9 & 6.8 & 6.9 & 6.7 \\
\hline 5days & 6.84 & 5.8 & 5.9 & 5.76 \\
\hline 6days & 6.78 & 5.23 & 5.36 & 5.12 \\
\hline
\end{tabular}

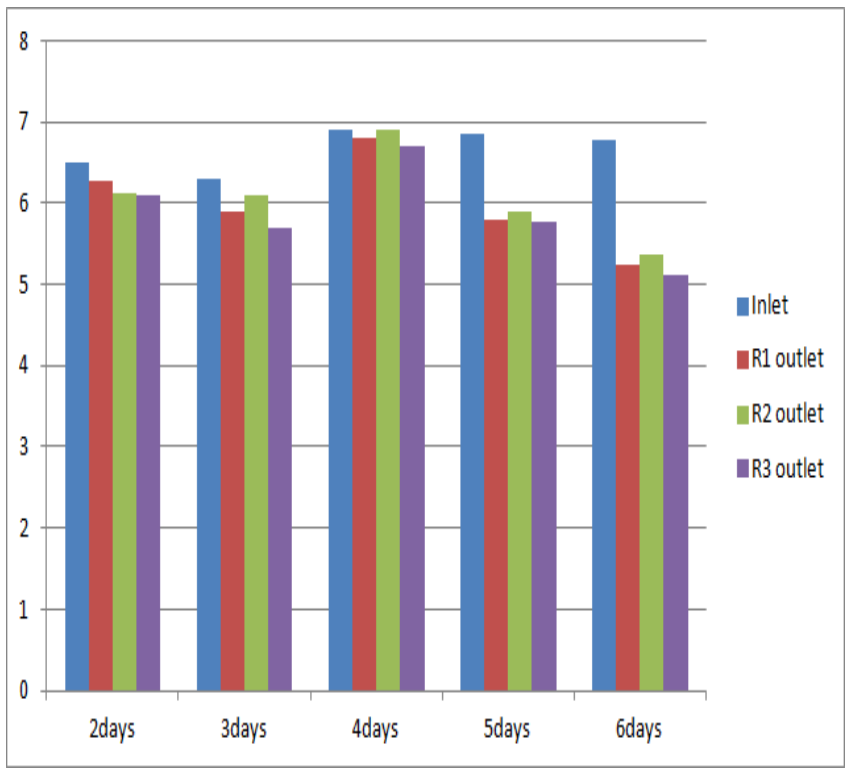

Fig. 6 Variations in $\mathrm{pH}$

Table 3 Observed DO in $\mathrm{mg} / \mathrm{lit}$

\begin{tabular}{|c|c|c|c|c|}
\hline $\begin{array}{c}\text { Detention } \\
\text { Time }\end{array}$ & Inlet & R1 outlet & R2 outlet & R3 outlet \\
\hline 2days & 7.64 & 7.6 & 7.5 & 7.54 \\
\hline 3days & 6.9 & 6.52 & 6.19 & 6.12 \\
\hline 4days & 6.8 & 6.2 & 5.8 & 5.76 \\
\hline 5days & 6.9 & 5.65 & 5.35 & 5.24 \\
\hline 6days & 7.1 & 6.8 & 6.45 & 6.16 \\
\hline
\end{tabular}

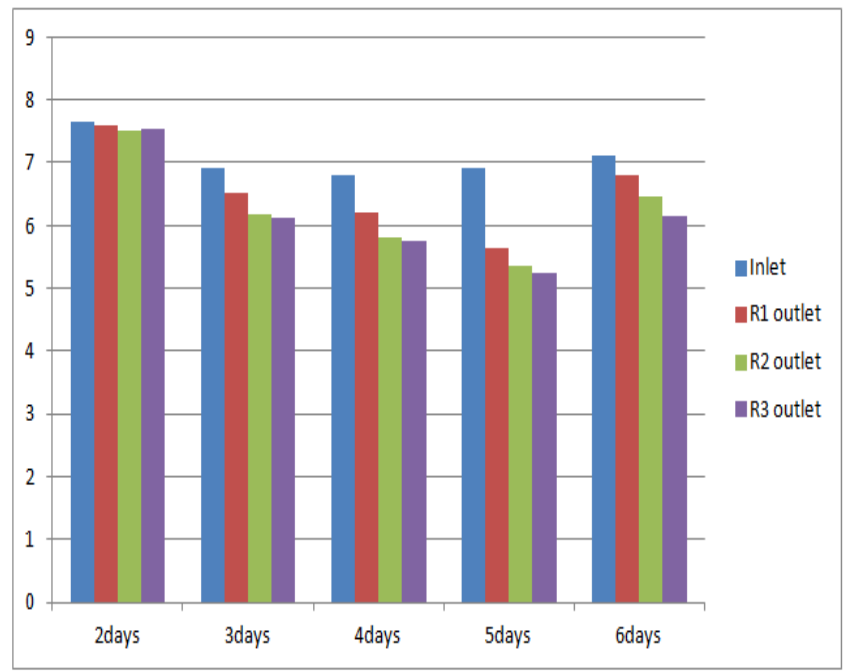

Fig. 7 Variations in DO in $\mathrm{mg} / \mathrm{lit}$ 
Table 4 Observed TP reduction

\begin{tabular}{|c|c|c|c|c|c|c|c|}
\hline $\begin{array}{c}\text { Detention } \\
\text { Time }\end{array}$ & Inlet & $\begin{array}{c}\text { R1 } \\
\text { outlet }\end{array}$ & $\begin{array}{c}\% \\
\text { removal }\end{array}$ & $\begin{array}{c}\text { R2 } \\
\text { outlet }\end{array}$ & $\begin{array}{c}\% \\
\text { removal }\end{array}$ & $\begin{array}{c}\text { R3 } \\
\text { outlet }\end{array}$ & $\begin{array}{c}\% \\
\text { removal }\end{array}$ \\
\hline 2days & 11.16 & 10.98 & 1.61 & 10.91 & 2.24 & 10.69 & 4.21 \\
\hline 3days & 11.8 & 11.34 & 3.89 & 10.91 & 7.54 & 10.83 & 8.22 \\
\hline 4days & 11.37 & 10.25 & 9.85 & 9.78 & 13.98 & 9.62 & 15.39 \\
\hline 5days & 11.31 & 9.63 & 14.77 & 9.3 & 17.7 & 8.98 & 20.6 \\
\hline 6days & 11.29 & 9.6 & 15 & 9.12 & 19.22 & 8.86 & 21.52 \\
\hline
\end{tabular}

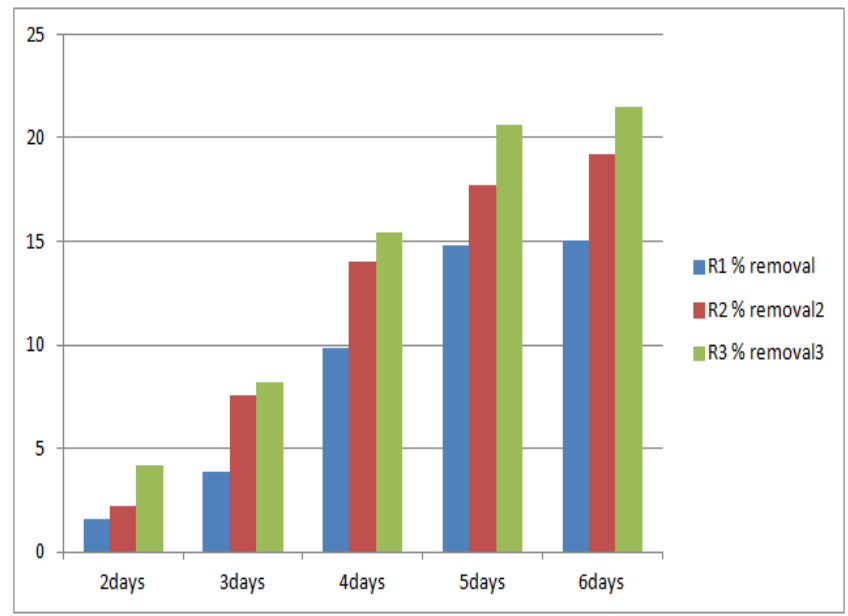

Fig. 8 Percentage reduction of TP in $\%$

Table 5 Observed TN reduction

\begin{tabular}{|c|c|c|c|c|c|c|c|}
\hline $\begin{array}{c}\text { Detention } \\
\text { Time }\end{array}$ & Inlet & $\begin{array}{c}\text { R1 } \\
\text { outlet }\end{array}$ & $\begin{array}{c}\% \\
\text { removal }\end{array}$ & $\begin{array}{c}\text { R2 } \\
\text { outlet }\end{array}$ & $\begin{array}{c}\% \\
\text { removal }\end{array}$ & $\begin{array}{c}\text { R3 } \\
\text { outlet }\end{array}$ & $\begin{array}{c}\% \\
\text { removal }\end{array}$ \\
\hline 2days & 12.28 & 11.96 & 2.6 & 11.7 & 4.7 & 11.2 & 8.79 \\
\hline 3days & 12.7 & 12.06 & 5.03 & 10.45 & 17.7 & 10.1 & 20.47 \\
\hline 4days & 12.56 & 10.17 & 19.02 & 9.94 & 20.85 & 9.89 & 21.46 \\
\hline 5days & 12.5 & 9.86 & 21.12 & 9.8 & 21.6 & 8.6 & 31.2 \\
\hline 6days & 12.3 & 9.1 & 26.01 & 8.91 & 27.56 & 7.8 & 36.58 \\
\hline
\end{tabular}

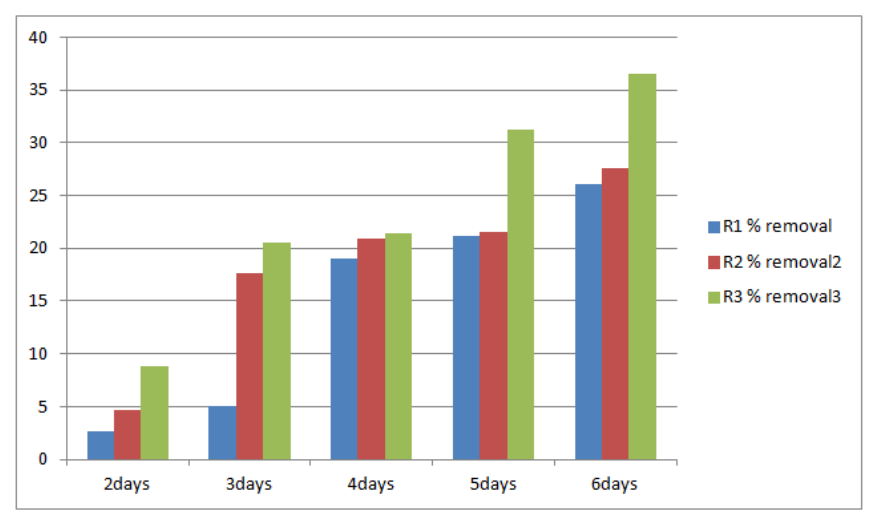

Fig. 9 Percentage reduction of TN in \%

As detention time increases, increase in the nutrient removal efficiency observed.

$$
6 d>5 d>4 d>3>2 d
$$

AFI technique showed a declining trend of $\mathrm{pH}$ by $0.5-1.5$. With increase in detention time, decrease in $\mathrm{pH}$ value recorded. Decrease in dissolved oxygen concentrations from beginning to the end was observed. This might be because reduced surface turbulence and increased shading of floating platform. Total nitrogen reduction was more than total phosphorus in all three reactors. USEPA has established a recommended limit to control eutrophication but these limits are for the streams entering lakes and flowing waters. For total phosphorus recommended limit is
$0.05 \mathrm{mg} / \mathrm{l}$ for the streams entering lakes and for the streams entering the flowing waters is $0.1 \mathrm{mg} / \mathrm{l}$. As per USEPA the acceptable range of total nitrogen is $2-6 \mathrm{mg} / \mathrm{lit}$. Cana indica is more efficient in removal of nutrient than the cyprus scariosus and typha minima. Nutrient removal efficiency of cyprus scariosus is very less.

\section{CONCLUSION}

Cana indica and typha minima are effective vegetation for removal of nutrient. But maximum percentage of nutrient removal has not observed for $52.7 \%$ vegetation cover and 6 plants per $0.0527 \mathrm{~m}^{2}$. Thus, either by increasing number of plants per $\mathrm{m}^{2}$ or increasing vegetation coverage is necessary to enhance the maximum effectiveness of nutrient removal. Increasing number of plants per $\mathrm{m} 2$ is a good option instead of increasing vegetation coverage because this vegetation coverage acts as a barrier to dissolution of atmospheric oxygen.

\section{REFERENCES}

[1] K.R. Reddy \& T.A. DeBusk, "State-of-the-art utilization of aquatic plants in waterpollution control", Water Sci. Technol. 19 (1987)

[2] Yao K, Song S, Zhang Z, Xu J, Zhang R, Liu J, Cheng L and Liu J., (2011), "Vegetation characteristics and water purification by the artificial floating island." African Journal of Biotechnology, 10(82), 19119-19125.

[3] Natalia Pavlineri, Nikolaos Th. Skoulikidis, Vassilios A. Tsihrintzis, "Constructed floating wetland: a review of research, design, operation and management aspects, and metaanalysis". Chemical engineering journal, S13858947(16)31385-7.

[4] Juan Huang, Shi-he wang, Lu Yan and Qui-shuangZhaong. "Plant photosynthesis and its influence on removal efficiencies in constructed wetland". Ecological Engineering 36 (2010) 10371043.

[5] Jan Vymazal. "Removal of nutrients in various types of constructed wetlands", Sci. TotalEnviron. 380 (2007) 48-65.

[6] S.A. White and M.M. Cousins, Floating treatment wetland aided remediation of nitrogenand phosphorus from simulated stormwater runoff, Ecol. Eng. 61 (2013) 207-215.

[7] H. Song, X. Li, W. Li and X. Lu. "Role of biologic components in a novel floating-bed combining Ipomoea aquatic, Corbiculaflumineaand biofilm carrier media", Front. Environ. Sci. Eng. 8 (2014) 215-225.

[8] Peter Nichols, Terry Lucke, Darren Drapper and Chris Walker, "Performance Evaluation of a Floating Treatment Wetland in an Urban Catchment". Water 2016, 8, 244.

[9] Frank M. Stewart, Tim Mulholland, Alfred B. Cunningham, Bruce G. Kania and Mark T. Osterlund. "Floating islands as an alternative to constructed wetlands for treatment of excess nutrients from agricultural and municipal wastes - results of laboratory-scale tests". Land Contamination \& Reclamation, 16 (1), 2008.

[10] PronotiDeshmukh and Mr. S. J. Mane, “ECO Engineered Remedy for Water Pollution using Artificial Floating Island”.GRD Journals | Global Research and Development Journal for Engineering | Recent Advances in Civil Engineering for Global Sustainability March 2016.

[11] Hsiao-Ling Lu, Chen-Ruei Ku and Yuan-Hsiou Chang, "Water quality improvement with artificial floating island". Ecological Engineering 74 (2015) 371-375.

[12] Rashmi Kamble and DhawalPatil, "Artificial Floating Island: Solution to River Water Pollution in India.Case Study: Rivers in Pune City”. 2012 International Conference on Environmental, Biomedical and Biotechnology IPCBEE vol.41 (2012).

[13] T. R. Headley and C.C. Tanner, "Floating Treatment Wetlands: An Innovative Option for Stormwater Quality". 11th 
International Conference on Wetland Systems for Water Pollution Control.

[14] Chris C Tanner and Tom Headley (2008), "Floatingtreatment wetlands -an innovative solution to enhance removal of fine particulates, copper and zinc" The NzwwaJournal • July 2008.

[15] Mian-Hao, Ju-Hong Y., Xiao-E., Zhen-Li, (2010), "Effects of temperature on purification of eutrophic water by floating ecoisland system." ActaEcologicaSinica30, 310-314

[16] F. Zhao, W. Yang, Z. Zeng, H. Li, X. Yang, Z. He, B. Gu, M.T. Rafiq, H. Peng, "Nutrient removal efficiency and biomass production of different bioenergy plants inhypereutrophic water, Biomass and Bioenergy". 42 (2012) 212-218.

[17] S.K. Billore, Prashant, J.K. Sharma, "Treatment performance of artificial floating reed in an experimental mesocosm to improve the water quality of kshipra". Water SciTechol. 60(2009) 28512859

[18] Brix H., (1997), "Plants Used in Constructed Wetlands and Their Functions."1 StInternational Seminar on the Use of Aquatic Macrophytes for Wastewater Treatment in Constructed Wetland.

[19] Agostinho, AA, Pelicice, FM., Petry, AC., Gomes, LC. and Julio Jr., HF., 2007. Fish diversity in the upper Parana River basin: habitats, fisheries, management and conservation. Aquatic Ecosystem Health \& Management,10(2), pp. 174-186.

[20] Ofek M., Hadar Y., and Minz D. "Colonization of cucumber seeds bybacteria during germination." Environmental Microbiology, 13(10), 2794-2807. (2011)

[21] Rohini Nitturkar and Shrikant Bhosale "Water quality improvement by artificial floating island: a review". IJRAR. January 2019.

[22] Sheoran A. and Sheoran V. "Heavy metal removal mechanism of acid mine drainage in wetlands: A critical review". Minerals Engineering, 105-116. (2006) 